\title{
Negara dan Alquran di Indonesia: Studi Kasus Tafsir Tematik Kementerian Agama Islam
}

Wildan Imaduddin Muhammad

Pusat Studi Qur'an (PSQ)

Imaduddinm045@gmail.com

Abstract: This article discusses scientific interpretation of the Quran by ministry, done by of religious the researcher. This qualitative study discusses how the interpreters selected by the ministry interpret verses about the creation of human. This article finds that they interpret the verses of the Quran, using scientific sources and logic to explain them which are related to sains.

Keywords: Tafsir'Ilmi, The Ministry of Religion, Method

Abstrak: Artikel ini membahas isyarat ilmiah dalam karya tafsir Kementerian Agama Islam RI, yang dilakukan oleh para peneliti agama. Penelitian kualitatif ini membahas bagaimana penafsir yang dipilih oleh kementerian untuk menafsirkan ayat-ayat tentang penciptaan manusia. Artikel ini menemukan bahwa mereka menafsirkan ayat-ayat Alquran, menggunakan sumber-sumber ilmiah dan logika untuk menjelaskan yang berhubungan dengan sains.

Kata kunci: Tafsir Ilmi, Kementerian Agama, Metode

\section{Pendahuluan}

Dalam perkembangan tafsir Alquran, muncul satu corak tafsir (al-lawn al-tafsïr ${ }^{1}$ yang mengakomodasi hubungan antara ayat Alquran dengan fenomena ilmu pengetahuan. Corak tafsir ini dikenal dengan istilah tafsir ilmi atau tafsir saintifik. Husain al-Żahabi mendefinisikan tafsir ilmi sebagai tafsir yang menguraikan isyaratisyarat ilmiah dalam ayat Alquran dan berupaya untuk menemukan titik temu diantara perkembangan ilmu pengetahuan dan pandangan para ilmuwan dengan Alquran. ${ }^{2}$

${ }^{1}$ Sarjana ulum Alquran yang memunculkan istilah al-lawn al-tafsìr, sejauh pencarian penulis, adalah al-Zarqani ; lihat selengkapnya : Muhammad Abd al-Aẓim al-Zarqani, Manāhịil al-'Irfān fì 'Ulüm al-Qur'ān, jilid 2 (Bairūt: 'Isa al-Bāb, t.t.), 170.

${ }^{2}$ Muḥammad Ḥusain al-Żahabi, Al-Tafsīr wa al-Mufassirūn, jilid 2 (Qāhirah: Maktabah Waḥbah, t.t.), 349 . 
Paradigma yang dibangun oleh tafsir ilmi adalah bahwa Alquran dalam ayatayatnya mengandung isyarat ilmiah yang jika diamati, maka dapat menghantarkan pembaca atau penafsir pada kesimpulan bahwa temuan-temuan ilmiah sejalan dengan Alquran. Pandangan mengenai Alquran yang dapat dijadikan sumber ilmu pengetahuan bukanlah barang baru yang muncul setelah abad modern, tetapi telah ada sejak abad ke$10 \mathrm{M}$, di saat perkembangan Sains di dunia Islam sedang berada di puncak keemasannya. $^{3}$

Salah satu ulama yang memproklamirkan bahwa di dalam Alquran terdapat kandungan ilmu pengetahuan secara luas adalah Abū Ḥamīd Al-Ghazālī. Dengan mengutip perkataan Ibn Mas'ud Al-Ghazālī mengatakan bahwa Alquran mengandung ilmu yang sangat luas, baik ilmu-ilmu klasik maupun ilmu futuristik. ${ }^{4}$ Sama seperti AlGhazāī̄, Badruddin al-Zarkāsȳ̄ yang juga mengutip Ibn Mas'ud mengatakan bahwa orang yang ingin menguasai berbagai ilmu hendaknya mempelajari Alquran. ${ }^{5}$ Ia menambahkan, di dalam Alquran terdapat berbagai ilmu yang jika dipelajari maka terdapat petunjuk (al-Burhān) ketuhanan. ${ }^{6}$

Contoh paling baik dari tafsir corak ilmi adalah Al-Jawāhir fì al-Tafsīr al-Qurān al-Karìm: al-Musytamil 'Alā 'Ajā'ibi Badā'i al-Mukawwanāt wa Gharā'ib al-Ayāt karya Tanțāwī Jauhārī (1870-1940). Dengan metode taḥlīli, tafsir ini menguraikan Alquran secara utuh 30 juz hingga menghasilkan karya tafsir sebanyak 25 jilid. Bisa dikatakan bahwa Tanțāwī Jauhārī adalah mufassir pertama yang menyengaja untuk menyusun kitab tafsir lengkap dengan corak ilmi, sebagaimana tercermin dalam judul kecil karya ini. Tetapi di dalam pengantar, Tanțāwī Jauhārī mengatakan bahwa selain sebagian besar porsi penjelasannya bersifat ilmiah, ia juga tidak luput menyertakan penjelasan tentang hukum dan akhlak. ${ }^{7}$ Hal ini membuktikan walaupun seorang

\footnotetext{
${ }^{3}$ Para ilmuwan berpengaruh yang menghiasi kemajuan dunia Islam antara lain: Al-Farābī (w. 951), Ibn Sīna (w. 1037), dan Ibn Rusyd (w. 1198). Pemikiran dan karya mereka banyak diterjemahkan dan dikaji di dunia barat. Lihat: Herbert A. Davidson, Al-Farābī, Avicenna, and Averroes on Intellect: Their Cosmologies, Theories of the Active Intellect, and Theories of Human Intellect (Oxford: Oxford University Press, 1992), 3.

${ }^{4}$ Redaksi yang sesuai dengan kitabnya adalah: من أراد علم الأولين و الآخرين فليتدبر القرآن... selengkapnya: Abū Ḥamīd al-Ghazālī, Ihyyā' 'Ulūm al-Dīn, jilid 1 (Bairūt: Dār al-Ma'rifah, t.t.), 289. 1954), 8 .

${ }^{5}$ Badruddīn al-Zarkāsyī, al-Burhān fì 'Ulūm al-Qur'ān (Qāhirah: Dār Iḥyā' al-Quṭb al-'Arabiyah,

${ }^{6}$ Badruddīn al-Zarkāsȳi, al-Burhān fì 'Ulūm al-Qur'ān, h. 8.

${ }^{7}$ Ketika Tanțāwī menafsirkan surat al-Fātihahạ, misalnya, ia memulai penjelasan dari riwayat Abū Hurairah tentang keutamaan surat al- Fātiḥah dari surat-surat yang lain. Meski pada pemaparan selanjutnya ia menghubungkan sifat Allah yang Maha Terpuji, sebagaimana terkandung pada ayat
} 
mufassir Alquran menghendaki penafsiran bercorak ilmiah, tetap tidak bisa dilepaskan dari tujuan utama wahyu Alquran yakni sebagai pedoman syariat.

Upaya-upaya penyelarasan ilmu saintifik dengan ayat Alquran kemudian dilanjutkan penyemaiannya oleh tokoh seperti Maurice Bucaille, ${ }^{8}$ seorang sarjana Barat dari Perancis, Zaghl al-Najjār dari Mesir, ${ }^{9}$ dan juga Harūn Yahyā, warga negara Turki. ${ }^{10}$ Ketiganya sama-sama memiliki latar belakang ilmu sains yang menemukan kecocokan hasil temuan mereka dengan ayat Alquran. Namun dari ketiga tokoh ini, dapat dikatakan bahwa Zaghl al-Najjār lebih produktif dengan banyak karya yang berbicara tentang hubungan Alquran dan sains modern.

Semangat membaca Alquran lewat perspektif saintifik tidak hanya ramai dilakukan para sarjana dari Timur Tengah dan Barat, tetapi juga ikut digeluti para ilmuwan di tanah air. Sejak akhir abad ke-20, tepatnya pada tahun 1995 telah muncul buku dengan judul Alquran Ilmu Pengetahuan dan Teknologi yang ditulis oleh Achmad Baiquni. ${ }^{11}$ Hal ini membuktikan semacam konsensus bersama di kalangan para ilmuwan Muslim yang mengkaji Alquran bahwa tafsir Ilmi dapat diterima secara luas.

Alhamdulillāhi Rabb al-'Ālamīn, dengan penciptaan hewan-hewan khususnya hewan yang disebutkan dalam Alquran, dan juga memasukkan teori-teori ilmiah Barat tentang karakteristik hewan tersebut. Tanțāwī Jauhārī, Al-Jawāhir fì al-Tafsīr al-Qurān al-Karīm: al-Musytamil 'Alā 'Ajā'ibi Badā'i alMukawwanāt wa Gharā 'ib al-Ayāt, jilid 1 (Qāhirah: Musțafā' al-Bābī, 1351), 3.

${ }^{8}$ Maurice Bucaille (1920-1998) berprofesi sebagai seorang ahli bedah anatomi. Ia pernah meneliti Mumi Firaun pada saat masa pemerintahan Presiden Anwar Sadat tahun 1974. Kiprahnya di dunia relasi Quran dan Sains berawal sejak terbit bukunya yang berjudul La Bible, Le Coran et la Science (1974). Beberapa tahun kemudian, buku ini diterjemahkan ke dalam bahasa Inggris dengan judul The Bible, The Quran, and Science.

${ }^{9}$ Dikenal juga dengan nama Zaghl El-Naggar (ejaan Inggris) yang lahir pada tahun 1933, dia adalah seorang geolog Mesir lulusan Ph.D dari University of Wales, UK. Jabatannya terakhir sebagai Kepala Badan Umum Mukjizat Ilmiah Alquran dan Sunnah (al-Hai'ah al- 'Alamiyyah li al-I'jāz al- 'Ilmī fì al-Qur'ān wa al-Sunnah). Penulis sedikitnya dapat menemukan enam karya yang ditulis oleh Zaghl yaitu: Mausū'at al-I'jāz al-l'Ilmī fì al-Qur'ā' wa al-Sunnah (2003), Min Āyat al-I'Jāz al-'Ilmī: Al-Arḍ fì alQur'ā' al-Karīm (2005), Min Āyat al-I'jāz al-'Ilmī: Al-Hayawān fì al-Qur'ān al-Karīm (2006), Min Āyat al-I'jāz al- 'Ilmī: Al-Samā' fì al-Qur'ā' al-Karīm (2007), Madkhal Ilā Dirāsat al-I'Jāz al- 'Ilmī fì al-Qur'ā' wa al-Sunnah al-Nabawiyyah al-Muțahhirah (2009), dan Min Āyat al-I'jāz al-Inbā'i wa al-Tarīkhi fì ALQur'à' al-Karìm (2013).

${ }^{10}$ Harūn Yahyā adalah nama pena dari Adnan Oktar yang lahir di Turki pada tahun 1956. Dia menyelesaikan studi S3 di Universitas Istanbul. Karya-karya yang dapat ditemukan oleh penulis diantaranya: The Basic Concepts of The Quran (2000), Miracles of The Quran (2001), Solution The Values of The Quran (2001), Learning from The Quran (2003), True Wisdom Describe in the Quran (2003), An Index to The Quran (2003).

${ }^{11}$ Achmad Baiquni (1923-1998) adalah professor pertama dari Indonesia yang menekuni bidang fisika atom dan nuklir. Ia menyelesaikan pendidikan master dan doktoral di Universitas Chicago, AS. Ada dua buku yang ia tulis tentang Alquran dan Ilmu Pengetahuan, pertama berjudul Alquran, Ilmu Pengetahuan dan Teknologi (1995) dan kedua berjudul Alquran dan Ilmu Pengetahuan kealaman (1997). Menurut Ulya Fikriyati, tafsir ilmi yang ditulis oleh Achmad Baiquni lebih menekankan kepentingan ideologis dibandingkan kebutuhan pragmatis. Artinya, teori ilmiah yang telah ditemukan dijadikan legitimasi pembenaran ayat Alquran, bukan ayat Alquran yang memicu ditemukannya teori-teori ilmiah. 
Selain menjadi fokus kajian perorangan, lembaga pemerintah dalam hal ini Kementerian Agama Republik Indonesia melalui Lajnah Pentashihan Mushaf Alquran (selanjutnya LPMQ) juga turut andil menggairahkan ranah penafsiran Alquran berbasis pendekatan ilmu kealaman. Bekerjasama dengan Lembaga Ilmu Pengetahuan Indonesia (LIPI), Lajnah Pentashihan Mushaf Alquran yang berada di bawah nauangan Badan Penilitian dan Pengembangan Kemenag RI berhasil menghasilkan sebanyak tiga belas buku tafsir tematik yang disusun sejak tahun 2009 dan terbit secara bertahap hingga tahun 2012. ${ }^{12}$

Penelitian atas Tafsir Ilmi Kemenag telah banyak dilakukan, satu diantaranya oleh Julkarnain (2014). Menurutnya, ada tiga faktor yang menjadi implikasi epistemologis dari lahirnya tafsir ilmi ini yaitu: kesadaran teologis, etika religius, dan maksimalisasi program pemerintah. ${ }^{13}$ Yang menjadi pembeda antara penulis dengan penelitian terdahulu adalah fokus kajian penulis pada satu seri buku dengan judul Kisah Para Nabi Pra-Ibrahim Dalam Perspektif Alquran dan Sains. Perdebatan mengenai apakah kisah Alquran fakta atau fiktif menjadi hal yang paling menjadi sorotan dari dua perspektif yang berbeda. Mengingat bahwa dalam menyikapi kisah Alquran para sarjana Muslim berbeda pandangan, maka penelitian atas buku ini menjadi hal yang menarik untuk dikaji.

Artikel ini akan mengkesplorasi argumentasi dan data yang dipaparkan dalam buku tersebut hingga sejauh mana kisah Alquran dapat dibuktikan melalui fakta sejarah.

\section{Profil Lajnah Pentashihan Mushaf Alquran (LPMQ)}

Sebelum mengenal lebih lanjut Tafsir Ilmi Kementerian Agama, ${ }^{14}$ ada baiknya penulis menguraikan terlebih dahulu sejarah dan profil singkat dari institusi yang memiliki proyek tafsir ini. Berdirinya $\mathrm{LPMQ}^{15}$ diawali dengan masuknya modernisasi percetakan di awal abad ke-20. Pada saat itu, produksi mushaf Alquran turut

Lihat: Ulya Fikriyati, "Tafsir Ilmi Nusantara: Antara Kepentingan Ideologis dan kebutuhan Pragmatis (Menimbang Tafsir Karya Ahmad Baiquni)" dalam Jurnal Al-Burhan XIII, 2 (2013), 51-67.

${ }^{12}$ Muhammad Shohib, "Sambutan dan Kata Pengantar" dalam Kisah Para Nabi Pra-Ibrahim Dalam Perspektif Alquran dan Sains (Jakarta: Kemenag, 2012), xi-xii.

${ }^{13}$ Muhammad Julkarnain, "Epistemologi Tafsir Ilmi Kemenag: Tumbuhan dalam Perspektif Alquran dan Sains" dalam Jurnal Penelitian Keislaman 10, 1 (2014), 1-26.

${ }^{14}$ Faizin, "Integrasi Agama Dan Sains Dalam Tafsir Ilmi kementrian Agama RI", Jurnal ushuluddin 25, 1 (2017), 24. 191.

${ }^{15}$ Rohimin, "jejak Dan Otoritas Pencetakan Mushaf Alquran di Indonesia” Nuansa IX, 2 (2016), 
terpengaruh sehingga ikut diproduksi secara massal oleh berbagai penerbit. Masingmasing penerbit pada waktu itu melakukan pentashihan sendiri-sendiri, seperti penerbit Alquran Matba'ah al-Islamiyah Bukittinggi 1933 M di tashih oleh al-Syaikh Sulaimān al-Rasūlī dan al-Ḥājj Abd al-Mālik, penerbit Abdullah bin Afif Cirebon 1352 H/1933 M ditashih oleh al-Ḥājj Muḥammad Uṡman dan al-Ḥājj Aḥmad al-Badāwī, dan lain-lain.

Sebagai wujud perhatian pemerintah untuk menjamin kesucian teks Alquran dari berbagai kesalahan dan kekurangan dalam penulisan Alquran, pada tahun 1957 dibentuk suatu lembaga kepanitiaan yang bertugas mentashih (memeriksa/mengoreksi) setiap mushaf Alquran yang akan dicetak dan diedarkan kepada masyarakat Indonesia. Lembaga tersebut diberi nama Lajnah Pentashih Mushaf Alquran. Keberadaan lembaga ini tidak muncul dalam struktur tersendiri, dan hanya merupakan semacam panitia adhoc. Lembaga tersebut menjadi bagian dari Puslitbang Lektur Keagamaan dan dalam PMA no. 3 tahun 2006 tentang organisasi dan Tata Kerja Departemen Agama.

Tugas-tugas Lajnah semakin berkembang sejalan dengan perkembangan zaman dan ilmu pengetahuan. Pada tahun 1982 keluar Peraturan Menteri Agama Nomor 1 tahun 1982, yang isinya antara lain menyebut tugas-tugas Lajnah Pentashih, yaitu (1) meneliti dan menjaga mushaf Alquran, rekaman bacaan Alquran, terjemah dan tafsir Alquran secara preventif dan represif; (2) mempelajari dan meneliti kebenaran mushaf Alquran, Alquran untuk tunanetra (Alquran Braille), bacaan Alquran dalam kaset, piringan hitam dan penemuan elektronik lainnya yang beredar di Indonesia; dan (3) Menyetop peredaran Mushaf Alquran yang belum ditashih oleh Lajnah Pentashih Mushaf Alquran.

Sepanjang perjalanan Lajnah sejak pertama kali didirikan pada tahun 1957 telah mengalami beberapa pergantian kepemimpinan. Sebutan untuk pemimpin Lajnah hingga akhir tahun 2006 adalah Ketua Lajnah yang secara ex officio dijabat oleh Kepala Puslitbang Lektur Keagamaan. Sejak awal tahun 2007 sejalan dengan ditetapkannya Lajnah Pentashihan Mushaf Alquran (LPMA) sebagai satuan kerja (satker) tersendiri, sebutan Ketua Lajnah berubah menjadi Kepala Lajnah Pentashihan Mushaf Alquran.

Tugas-tugas Lajnah hingga tahun 2007 masih sebatas mentashih Alquran dengan segala macam produknya. Namun belakangan ini tugas-tugas Lajnah menjadi semakin luas. Sehubungan dengan itu, sebagai tindak lanjut pelaksanaan Peraturan Menteri Agama Republik Indonesia Nomor 3 Tahun 2006 tentang Organisasi dan Tata Kerja 
Departemen Agama dan untuk meningkatkan dayaguna dan hasil-guna pelaksanaan tugas dibidang pentashihan dan pengkajian Alquran, keluarlah Peraturan Menteri Agama RI Nomor 3 Tahun 2007 tentang Organisasi dan Tata Kerja Lajnah Pentashihan Mushaf Alquran.

Di dalam Peraturan Menteri Agama RI Nomor 3 Tahun 2007 Bab I pasal 1, Lajnah Pentashihan Mushaf Alquran adalah Unit Pelaksana Teknis Badan Penelitian dan Pengembangan serta Pendidikan dan Pelatihan, berada di bawah dan bertanggung jawab kepada Kepala Badan Litbang dan Diklat Kementerian Agama RI.

Sejak keluarnya PMA tersebut, Organisasi dan Tata Kerja Lajnah Pentashihan Mushaf Alquran turut berubah sesuai dengan tugas dan fungsi Lajnah dalam diktum tersebut, sehingga organisasi ini mencakup 3 bidang, yaitu (1) Bidang Pentashihan, (2) Bidang Pengkajian Alquran, dan (3) Bidang Bayt Alquran dan Dokumentasi. Khusus pengelolaan Bayt Alquran dan Museum Istiqlal telah diterbitkan pula Keputusan Menteri Agama No. 45 Tahun 2007tentang Pencabutan Keputusan Menteri Agama Nomor E/50 Tahun 2002 tentang Susunan Personalia Pengelolaan Bayt Alquran dan Museum Istiqlal Taman Mini Indonesia Indah. Sejak keluarnya PMA No. 3 Tahun 2007 inilah tugas pengelolaan Bayt Alquran dan Museum Alquran di bawah Lajnah Pentashihan Mushaf Alquran.

\section{Penulisan Tafsir Ilmi Kemenag: Latar Belakang, Motivasi, dan Penyusunan}

Penulisan Tafsir Ilmi Kementerian Agama Republik Indonesia, sebagaimana telah diulas di bagian pendahuluan, dimulai sejak tahun 2009 atas kerjasama Lajnah Pentashihan Mushaf Alquran (LPMQ) yang berada di bawah naungan Badan Penelitian dan Pengembangan (Balitbang) Kemenag RI dengan Lembaga Ilmu Pengentahuan Indonesia (LIPI), Lembaga Penerbagan dan Antariksa Nasional (LAPAN) dan Observatorium Boscha Institut Teknologi Bandung (ITB) yang kemudian berakhir di tahun 2012 dengan menghasilkan sebanyak 13 buku tafsir.

Latar belakang penyusunan tafsir Ilmi ini adalah melaksanakan amanat konstitusi pada pasal 29 UUD 1945 yang pada kemudian diturunkan menjadi peraturan perundang-undangan. Salah satunya adalah Peraturan Presiden RI No. 5 Tahun 2010 tentang Rencana Pembangunan Jangka Menengah (RPJM) 2010-2014 dengan fokus

prioritas peningkatan kualitas kehidupan beragama dengan empat rincian, yakni: a. 
Peningkatan kualitas pemahaman dan pengalaman agama, b. Peningkatan kualitas kerukunan antar umat beragama, c. Peningkatan kualitas pelayanan kehidupan beragama, dan d. Pelaksanaan ibadah haji yang tertib dan lancar. ${ }^{16}$ Berdasarkan empat rincian fokus prioritas peningkatan kualitas kehidupan beragama di atas, maka penyusunan serial tafsir ilmi ini termasuk pada poin yang pertama yakni peningkatan kualitas pemahaman dan pengalaman agama.

Motivasi penyusunan tafsir, dapat dilihat dari pernyataan-pernyataan yang diungkapkan para pemangku jabatan di Kementerian Agama seperti Suryadharma Ali selaku Menteri Agama dan Machasin sebagai kepala Balitbang Kemenag. Dalam pemahaman penulis dari ungkapan mereka, ada tiga hal yang dapat digarisbawahi. Pertama, pentingnya kesadaran membaca sebagaimana wahyu Alquran pertama kepada nabi Muhammad saw. Kedua, menghadirkan universalitas Alquran yang selalu relevan bagi setiap zaman yang tidak terkecuali dengan fenomena alam. Dan ketiga, tafsir ilmi dapat dijadikan landasan bagi munculnya ilmu kalam baru yang dapat memperteguh keimanan manusia modern dengan bukti-bukti ilmiah yang selaras dengan Alquran.

Penyusunan tafsir ilmi dilakukan oleh tim yang anggotanya secara keseluruhan dapat dikategorikan ke dalam dua bagian. Pertama, adalah tim yang berisi para pakar ilmu Alquran dan ilmu keislaman lainnya. Kedua, tim ahli di bidang ilmu alam seperti fisika, geologi, arkeologi, astronomi dan lain lain. Kelompok yang disebutkan pertama dapat disebut juga sebagai tim syar'i, sedangkan yang kedua dinamakan tim kauni. Semuanya bermusyawarah dan bersinergi untuk menafsirkan ayat-ayat kealaman dalam Alquran. Secara lengkap tim penyusun terdiri dari: ${ }^{17}$ (1) Pengarah: Kepala Badan penelitian dan pengembangan (Balitbang) Kementerian Agama RI, Kepala Lembaga Ilmu Pengetauan Indonesia (LIPI), dan Kepala Lajnah Pentashihan Mushaf Alquran, (2) Narasumber: Prof. Dr. H. Umar Anggara Jenie, Apt. M.Sc, Prof. Dr. M. Quraish Shihab M.A, Prof. Dr. M. Atho Mudzhar, Dr. KH. Ahsin Sakho MA, dan Prof. Dr. dr. Muhammad Kamil Tajudin, Sp.And, (3) Ketua: Prof. Dr. H. Hery Haryono, (4) Wakil Ketua: Dr. H. M. Muchlis Hanafi, MA, (5) Sekretaris: Dr. H. Muhammad Hisyam, (6) Anggota: Prof. Dr. Arie Budiman; Prof. Dr. Syamsul Farid Ruskanda; Prof. Dr. H. Hamdani Anwar, MA; Prof. Dr. H. Syibli Sardjaya, LML; Prof. Dr. Thomas

\footnotetext{
${ }^{16}$ Machasin, "Sambutan dan Kata Pengantar", xi-xii.

${ }^{17}$ Muhammad Shohib, Muhammad Shohib, "Sambutan dan Kata Pengantar" dalam Kisah Para Nabi Pra-Ibrahim Dalam Perspektif Alquran dan Sains, xiv-xv.
} 
Djamaluddin; Prof. Dr. H. Darwis Hude, M.Si; Dr. H. Mudji Raharto; Dr. H. Sumanto Imam Hasan; Dr. Hoemam Rozie Sahil; Dr. A. Rahman Djuwansyah; Ir. Dudi Hidayat, M.Sc; Abdul Aziz Sidqi, M.Ag. (7) Staf Sekretariat: Dra. Endang Tjempakasari, M. Lib; Muhammad Musaddad, S.Th.I; Zarkasi, MA; dan Sholeh, S.Ag.

Data-data di atas menunjukkan keseriusan para pemangku jabatan beserta para ilmuwan yang terlibat. Hal ini terlihat dari komposisi nama-nama panitia penyusun merupakan ahli di bidangnya dan diakui kompetensinya secara Nasional, bahkan Internasional.

\section{Tafsir Ilmi Kementerian Agama: Kisah Para Nabi Pra-Ibrahim dalam Perspektif}

\section{Alquran dan Sains}

Pada bagian ini akan diuraikan lebih dalam mengenai tafsir yang sedang diteliti dalam beberapa aspek: sumber penafsiran, metode dan corak, sistematika penulisan, dan contoh penafsiran. Aspek sumber penafsiran menjadi penting mengingat bahwa sebuah karya tafsir belakangan tidak dapat melepaskan diri dari produk penafsiran yang telah lebih dulu hadir dan menjadi konsumsi masyarakat. Begitu pun dengan metode dan corak penafsiran, dua hal ini menjadi gambaran penjelas bagaimana sebuah tafsir disusun dan memiliki spesifikasi di antara tafsir-tafsir lainnya. Sistematika penulisan tafsir memberikan penjelasan tentang bagaimana produk tafsir dijelaskan hingga pembaca dapat dengan mudah memahaminya. Adapun contoh penafsiran merupakan bahasan yang dapat dijadikan distingsi antara tafsir ini dengan tafsir ilmi lainnya.

\section{Sumber Penafsiran}

Berbeda dengan corak tafsir lain, tafsir ilmi, dengan kedalamannya untuk mengeksplorasi relasi antar petunjuk ayat Alquran dengan ilmu pengetahuan alam, tidak hanya bersumber pada kitab-kitab tafsir. Akan tetapi dilengkapi pula dengan sumber terbaru atas penemuan fenomena alam sesuai dengan ayat yang sedang ditafsirkan. Ketika berbicara tentang ayat tumbuhan, misalnya, rujukan lain selain penjelasan tafsir terdahulu adalah materi di bidang biologi dan lain semacamnya.

Melihat berbagai referensi yang dituliskan dalam daftar pustaka, sumber penafsiran buku yang sedang diteliti terdiri atas tiga bentuk: literatur (buku dan artikel), wawancara, dan website. Tentunya bentuk sumber yang pertama yang mendominasi 
keseluruhan sumber dibandingkan dengan sumber kedua maupun sumber terakhir. Namun demikian, tidak berarti dua yang terakhir itu tidak lebih penting dari sumber pertama. Meskipun memang, sumber literatur dalam hal penulisan buku tafsir tetap menjadi prioritas dibandingkan sumber dalam bentuk lain.

Sumber literatur terdiri atas 43 (empat puluh tiga) karya dalam tiga bahasa; Inggris, Arab, Indonesia. Sayangnya, untuk sumber literatur berbahasa Arab dan sebagian literatur bahasa Inggris, berdasarkan daftar pustaka, masih merujuk pada bukubuku terjemah bahasa Indonesia. Karya Syauqī Abū Khalīl, Muhammad al-Hanāfī, Samī’ al-Maghlūs̀, dan Hanāfī al-Maḥlawīe yang sumber aslinya berbahasa Arab, kesemuanya dirujuk pada sumber terjemahan berbahasa Indonesia. Begitu pun karya berbahasa Inggris seperti Lessons from the Stories of the Quran, merujuk pada terjemah dengan judul Pelajaran-Pelajaran dari Riwayat-Riwayat dalam Alquran. ${ }^{18}$

Polemik sumber terjemahan seperti yang diungkapkan di atas sebenarnya dapat dimaklumi, mengingat bahwa proyek penyusunan Tafsir Ilmi ini bukan merupakan karya akademik yang murni ilmiah dan harus dipertanggung jawabkan dan harus di hadapkanan pada sebuah sidang ujian. Melainkan kembali pada tujuan utama yakni sebagai bentuk upaya peningkatan kualitas pemahaman dan pengalaman agama rakyat Indonesia.

Secara garis besar, sumber referensi penafsiran yang dipakai oleh tim untuk memahami ayat Alquran tentang kisah Nabi pra-Ibrahim dapat dikategorikan menjadi tiga kelompok; tafsir/komentar Alquran, Sejarah, dan Arkeologi. Di kategori yang pertama, buku ini tidak merujuk sama sekali pada tafsir klasik ataupun modern yang umum diketahui semisal Al-Ṭabārī, Ibn Kas̀īr, ataupun Abduh, dan Tanțāwī Jauhārī. Melainkan rujukannya adalah komentar dari ‘Abdullah Yūsuf ‘Āli.

Hal ini terlihat tatkala menafsirkan Q.S Hūd [11]: 44, Yusuf 'Āli dikutip dalam kaitannya dengan penafsiran kata al-Jūdi. Menurut Yūsuf 'Āli, kata tersebut mengindikasikan tempat sebuah gunung yang terletak di suatu wilayah yang bernama Bohtan. Saat ini wilayah tersebut masuk teritori Turki dan merupakan daerah perbatasan yang dekat dengan Irak dan Suriah. ${ }^{19}$ Selebihnya, penafsiran-penafsiran dilakukan dengan menggunakan ayat dan hadis.

\footnotetext{
${ }^{18}$ LPMQ Kemenag RI, Kisah Para Nabi Pra-Ibrahim dalam Perspektif Alquran dan Sains (Jakarta: Kemenag RI, 2012), 144-146.

${ }^{19}$ LPMQ Kemenag RI, Kisah Para Nabi Pra-Ibrahim dalam Perspektif Alquran dan Sains, 67.
} 
Kategori kedua yaitu sumber sejarah. Sumber sejarah yang dirujuk berbentuk sumber sejarah geografis seperti karya Syauqī Abū Khalīl dan al-Maghlūì. Karya keduanya berupa atlas yang memperlihatkan gambaran letak geografis dimana kira-kira para nabi hidup dan menyebarkan ajaran mereka semasa dakwahnya. Perbedaan diantara keduanya adalah terletak pada penjabarannya. Jika Abū Khalīl menjelaskan satu per satu nabi dengan rincian letak geografis masing-masing dari mereka, maka AlMaghlūs cenderung membuat klasifikasi dengan memaparkan persebaran nabi di dunia secara global.

Dalam uraian Syauqī Abū Khalīl, para nabi dari mulai nabi Adam, peristiwa Qabil dan habil, nabi Idris hingga tempat-tempa penting selama perjalanan dakwah nabi Muhammad saw dijelaskan secara mendalam dan terperinci. ${ }^{20}$ Sedangkan penjelasan alMaghlūs tidak berkutat di penjelasan nabi dan Rasul secara detail, tetapi lebih menerangkan tempat-tempat peradaban yang disebutkan dalam Alquran, termasuk di dalamnya penjelasan tentang $Y a^{\prime} j \bar{u} z$ dan $M a{ }^{\prime} j \bar{u} z$ juga penjelasan tentang Dzulqarnain. ${ }^{21}$

Ketika menguraikan kisah nabi Adam, misalnya, baik Abū Khalīl maupun alMaghluts sama sama dijadikan rujukan. Al-Maghlūs̀ dikutip dalam pendapatnya mengenai tiga wilayah turunnya nabi Adam ke bumi. Uraian yang diambil adalah perbedaan pendapat mengenai tiga tempat menurut para ulama, tiga tempat tersebut yakni Dajna semenanjung Arab antara Mekah dan Tā’if, bukit Ṣāfa, dan India. ${ }^{22}$ Sedangkan Syauqi Abū Khalīl dikutip pendapatnya mengenai Adam yang turun di gunung Adam yang terletak di Sri Lanka. ${ }^{23}$ Tidak ada pendapat yang dipilih dan diunggulkan oleh tim Tafsir Ilmi kemenag dari semua pendapat yang diuraikan. Dalam arti bahwa semua pendapat dapat sama sama memiliki argumentasinya masing-masing tanpa perlu dipertentangkan satu sama lain.

Kategori sumber penafsiran yang terakhir adalah berangkat dari ilmu arkeologi. Sumber-sumber arkeologi terutama diambil sebagai referensi pada penjelasan awal tentang sejarah manusia dan sejarah kebudayaan manusia. Dalam amatan penulis, sedikitnya ada dua sumber primer yang dijadikan rujukan yakni Richard Leakey dan

\footnotetext{
${ }^{20}$ Misalnya saja tempat berlansungnya Haji Wada' Rasūlullah saw. Lihat: Syauq̄i Abū Khalīl, Aṭlās al-Qur'ān: Amākin, Aqwān, A'lām (Bairūt: Dār al-Fikr al-Mu'āṣir, 2003), 274.

${ }^{21}$ Sāmi' ibn 'Abdullah al-Maghlūs, Ațlās al-Anbiyā' wa al-Rusūl (Riyāḍ: Maktabat al-'Abīkan, 2005), 209.

${ }^{22}$ LPMQ Kemenag RI, Kisah Para Nabi Pra-Ibrahim dalam Perspektif Alquran dan Sains, 38-39.

${ }^{23}$ LPMQ Kemenag RI, Kisah Para Nabi Pra-Ibrahim dalam Perspektif Alquran dan Sains, 40.
} 
Gordon Childe. Dua tokoh ini sama-sama arkeolog yang diakui karena keseriusan mereka dalam meneliti bukti-bukti fosil di daerah Afrika dan Eropa.

Menurut Richard Leakey sebagaimana dikutip dalam buku Kisah Para Nabi PraIbrahim, ada empat tahap kunci proses penyempurnaan manusia, yakni pertama, berawal sekitar 7 juta tahun yang lalu ketika berkembang suatu spesies yang bergerak secara bipedal (berdiri dengan dua kaki). Kedua menyebarnya spesies bipedal itu dengan perkembangan penyesuaian diri di daerah yang berbeda (adaptive radiation) antara 7 sampai 2 juta tahun yang lalu. Ketiga, pembesaran otak yakni silsilah manusia yang tumbuh melalui homo erectus menjadi homo sapiens. Keempat, menjadi manusia modern seperti nabi Adam as. ${ }^{24}$

Gordon Childe berpendapat bahwa periode manusia modern dimulai sejak 25.000 tahun yang lalu. Adapun kebudayaan mereka secara bertahap dapat dibagi menjadi tiga zaman; Zaman Batu (tua dan baru), Zaman Perungggu, dan Zaman Besi. Di Zaman Batu lama (paleolithic) manusia hidup dengan cara berburu, menangkap ikan dan mengumpulkan buah-buahan serta berpindah-pindah tempat (nomaden). Lalu di Zaman Batu Baru (neolithic) manusia mulai mengenal bercocok tanam dan beternak hewan, pada zaman ini oleh para arkeolog diistilahkan dengan zaman revolusi pertanian. Kemudian Zaman Perunggu mulai ada kegiatan pertukangan, pengrajin, dan pedagang serta mulai dikenal transportasi dengan hewan peliharaaan. Terakhir Zaman Besi, yakni ketika perunggu terlebih batu mulai ditinggalkan. Perunggu pada waktu itu dianggap mahal karena timah dan tembaga sebagai bahan baku pembuat perunggu cukup langka. Akhirnya, pembuatan alat alat lebih mengutamakan bijih besi dan dimulailah revolusi perkotaan. $^{25}$

\section{Corak dan Metode Penafsiran}

Berbicara mengenai corak tafsir, ${ }^{26}$ penulis sependapat dengan definisi Abdul Mustaqim yang mengartikan corak tafsir sebagai nuansa khusus atau sifat khusus yang memberikan warna tersendiri terhadap tafsir. ${ }^{27}$ Dalam uraian berikutnya, Mustaqim

\footnotetext{
${ }^{24}$ LPMQ Kemenag RI, Kisah Para Nabi Pra-Ibrahim dalam Perspektif Alquran dan Sains, 2021.

${ }^{25}$ LPMQ Kemenag RI, Kisah Para Nabi Pra-Ibrahim dalam Perspektif Alquran dan Sains, 2425.

${ }^{26}$ Rohmansyah, “Corak Tafsir Muhammadiyah”, Jurnal Ushuluddin 2, 1 (2018), 34.

${ }^{27}$ Abdul Mustaqim, Dinamika Sejarah Tafsir Alquran: Studi Aliran Aliran Tafsir dari Periode Klasik, Pertengahan, Hingga Modern-Kontemporer (Yogyakarta: Adab Press, 2012), 112.
} 
memaparkan enam corak tafsir yang menurutnya disebabkan perbedaan spesialisasi intelektual mufassir dan sesuai keilmuan yang berkembang di dunia Islam. Enam corak tersebut adalah corak linguistik (al-tafsīr al-lughāwì), corak fikih (al-tafsīr al-fiqhi), corak teologis (al-tafsīr al-i'tiqādì), corak sufistik (al-tafsīr al-șüfì), corak falsafi (altafsīr al-falsafī), dan corak ilmi (al-tafsīr al- 'ilmī). ${ }^{28}$

Sebagaimana telah diulas di bagian pendahuluan, corak tafsir atau lawn al-tafsìr sangat jelas tergambar dalam judul besar dari serial tafsir ini yakni Tafsir Ilmi. Oleh karena itu, tidak diragukan lagi bahwa buku Kisah Para Nabi Pra-Ibrahim termasuk ke dalam corak tafsir ilmi.

Sebelum merinci langkah-langkah metodologis yang ditempuh Tafsir Ilmi Kemenag, ada beberapa fenomena yang menurut Muchlis M. Hanafi menjadi penyebab munculnya tafsir ilmi. Pertama, pengaruh perkembangan teknologi dan ilmu pengetahuan yang pesat di Eropa terhadap dunia Arab dan kawasan Muslim. Kedua, timbul kesadaran membentuk rumah baruh bagi peradaban Islam yang mengalami dualisme antara mengenang kedigdayaan masa lalu dan hasrat untuk memperbaiki diri.

Ketiga, perubahan cara pandang Muslim modern terhadap ayat Alquran dikarenakan adanya temuan-temuan ilmiah di abad ke-20. Keempat, tumbuhnya kesadaran memahami Alquran dengan sains modern dapat menjadi "ilmu kalam baru" yang dibandingkan dengan fenomena zaman dulu ketika ilmu kalam diperkenalkan dengan logika/filsafat, maka sudah saatnya pendekatan ilmiah/saintifik menjadi alternatif baru. ${ }^{29}$

Mengutip wawancara Zaghl al-Najjār dan juga pendapat Manșūr Hasāb al-Nabī, Muchlis M. Hanafi memaparkan tujuh langkah metodologis yang harus ditempuh dalam rangka melakukan penafsiran dengan pendekatan saintifik. Pertama, memperhatikan arti dan kaidah kebahasaaan. Kedua, memperhatikan konteks ayat yang ditafsirkan, korelasi antar ayat dan surah, bahkan kata dan kalimatnya. Ketiga, memeperhatikan penafsiran Rasulullah saw. selaku pemegang otoritatif tafsir Alquran, kemudian sahabat, tabiin, dan para ulama tafsir.

\footnotetext{
${ }^{28}$ Abdul Mustaqim, Dinamika Sejarah Tafsir Alquran: Studi Aliran Aliran Tafsir dari Periode Klasik, Pertengahan, Hingga Modern-Kontemporer, 113.

${ }^{29}$ Muchlis M. Hanafi, "Memahami Isyarat-Isyarat Ilmiah Alquran: Sebuah Pengantar" dalam Kisah Para Nabi Pra-Ibrahim dalam Perspektif Alquran dan Sains, xxii-xxiv.
} 
Keempat, tidak memperlakukan tafsir ayat-ayat isyarat ilmiah sebagai legitimasi hukum benar dan salah sebuah penemuan saintifik. Kelima, memperhatikan satu kata atau ungkapan dapat mengandung sekian makna. Keenam, memahami secara mendalam segala bentuk yang menyangkut objek bahasan ayat, termasuk penemuan ilmiah yang terkait dengannya. Ketujuh, tidak menggunakan hasil temuan ilmiah yang sifatnya masih bersifat hipotesis yang besar kemungkinan dapat berubah. ${ }^{30}$

\section{Sistematika Penulisan Karya Tafsir}

Pada bagian sistematika tafsir, sedikitnya ada dua hal yang perlu diulas. Pertama terkait dengan konten secara keseluruhan buku tafsir yang dimulai dengan penjelasan mengenai daftar isi. Kedua yang berhubungan dengan secara detail langkah-langkah penulisan tafsir dan interpretasi ayatnya.

Buku tafsir ilmi Kisah Para Nabi Pra-Ibrahim memuat lima bab yang secara terperinci terdiri dari pendahuluan, keberadaan nabi dan rasul, kisah para nabi/rasul praibrahim, kronologi nabi pra-ibrahim dan kaitannya dengan sejarah kebudayaan manusia, dan penutup. Di dua bab pertama, pemaparan lebih terkait pada hal-hal mengenai pengenalan konsep, ruang lingkup kajian, dan pendekatan dan metode yang digunakan dalam seluruh konten yang akan dikaji. Dalam hal ini konsep-konsep mengenai kisah Alquran (Qașāṣ al-Qur'ān), Israiliyat, dan dua metode yang dipakai yakni studi literatur, survei, ekskavasi (arkeologi), dan hermeneutika.

Bab ketiga berisi rincian nabi-nabi yang dibahas terkait dengan ayat-ayat yang muncul dalam Alquran, tulisan sejarah, dan bukti-bukti arkeologis yang dapat ditemukan. Adapun nabi-nabi yang dimaksud antara lain Nabi Adam, Nabi Syis, Nabi Idris, Nabi Nuh, Nabi Hud, Nabi Salih, dan Nabi Hanzalah. Terkait dengan nabi terkahir, meskipun tidak disebutkan dalam Alquran, tetapi dalam buku tafsir ini diidentifikasi sesuai dengan kaum yang menjadi tempat berdakwah yakni penduduk Rass. Di bab keempat pembahasan lebih mengerucut pada relasi kronologis kisah para Nabi Pra-Ibrahim dengan sejarah kebudayaan manusia.

Secara sistematis, penafsiran atas ayat-ayat tentang kisah Nabi Pra-Ibrahim dapat diklasifikasikan menjadi tiga pembahasan, yaitu:

\footnotetext{
${ }^{30}$ Muchlis M. Hanafi, "Memahami Isyarat-Isyarat Ilmiah Alquran: Sebuah Pengantar" dalam Kisah Para Nabi Pra-Ibrahim dalam Perspektif Alquran dan Sains, xxvi-xxvii.
} 
Pertama, Ayat-ayat Alquran yang berkenaan dengan Nabi yang sedang dibahas. Misalnya ketika menjelaskan tentang Nabi Adam, disebutkan beberapa ayat yang menceritakan Nabi Adam seperti Q.S al-Bāqarah [2]: 30-37, al-Hijr [15]: 26-33, dan ayat-ayat lain. Ketika membahas Nabi Idris, disebutkan berada dalam Q.S Maryām [19]: 56, dan al-Anbiyā' [21]: 85. Tatkala menjelaskan Nabi Nuh, disebutkan pula pembahasannya dalam Q.S Hūd [11]: 25-49. Juga nabi-nabi yang lain pada pembahasan awal pasti dimuat pemaparan tentang nabi yang sedang diulas yang kaitannya dengan penyebutan ayat Alquran.

Kedua, Catatan yang berkaitan dengan Nabi tersebut. Catatan yang maksudnya adalah beberapa pembahasan yang terkait langsung dengan Nabi yang sedang dibahas yang diambil dari sumber referensi kesejarahan maupun refrensi ilmu arkeologi. Nabi Adam dalam pembahasan catatan yang berkaitan, diulas tentang respon malaikat atas penciptaan khalifah di Bumi, kemampuan Nabi Adam dalam menyebutkan nama-nama benda, alasan Iblis enggan bersujud pada Adam, penciptaan Adam dari unsur tanah yang ditiupkan ruh, kutukan kepada iblis, tantangan iblis, hingga catatan tentang anak Nabi Adam Qabil dan Habil. Ketika membahas Nabi Idris, sebagai contoh lain, dijelaskan beberapa poin yakni tempat kelahirannya, nama dan nasabnya, riwayat tentang Nabi Idris, peristiwa pengangkatan ke langit, dan peristiwa pertemuan Rasulullah dengan Nabi Idris.

Ketiga, Hikmah yang dapat diambil dari kisah Nabi. Di setiap penjelasan NabiNabi selalu dipungkasi dengan hikmah atau pelajaran yang dapat diambil dari kisah para Nabi yang sedang dibahas. Seperti misal hikmah yang dapat dipetik dari kisah nabi Syis disebutkan ada tiga hal pokok. Pertama, perbuatan kriminal harus dibalas dengan hukuman pidana. Kedua, mengkultuskan sesuatu dalam bentuk pemberhalaan merupakan perbuatan syirik. Ketiga, keteladanan Nabi Syis untuk mencintai ilmu dan pengembangan. Contoh lain adalah hikmah dari kisah Nabi Hud. Ada tiga hikmah yang dapat diambil yakni ajaran tauhid yang didakwahkan Nabi Hud, kesabaran Nabi Hud dalam menghadapi kaumnya, dan menjauhi sifat sombong agar terlepas dari merasa paling benar. 


\section{Contoh-Contoh Penafsiran}

Di bagian sebelumnya telah diulas secara singkat sistematika penulisan, yang dalam hal ini akan sangat berkaitan erat dengan contoh-contoh penafsiran. Dari tiga komponen uraian dalam sistematika penulisan tersebut di atas, contoh penafsiran masing-masing dari pembahasan akan berbeda berkaitan dengan konten yang sedang dibahas. Misalnya saja pada saat pembahasan ayat Alquran, maka di bagian ini tidak ada penafsiran berarti selain penyebutan ayat dan terjemahannya.

Lain halnya dengan ketika membahas bagian yang kedua, catatan penting tentang riwayat Nabi yang sedang diulas, maka penafsiran secara mendetail akan mudah ditemukan. Seperti ketika menafsirkan Q.S al-Bāqarah [2]: 35 dan Q.S al-A'rāf [7]: 19 tentang pelanggaran yang dilakukan Nabi Adam yang bunyi ayatnya adalah sebagai berikut:

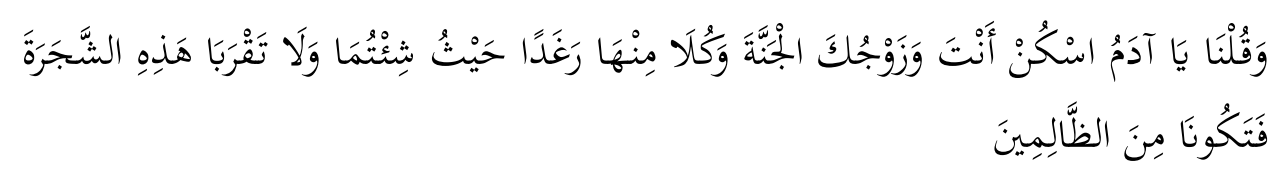

Dan Kami berfirman, "Wahai Adam! Tinggallah engkau dan istrimu di dalam surga, dan makanlah dengan nikmat yang ada di sana sesukamu. (tetapi) janganlah engkau dekati ini, nanti kamu termasuk orang-orang yang zalim!"

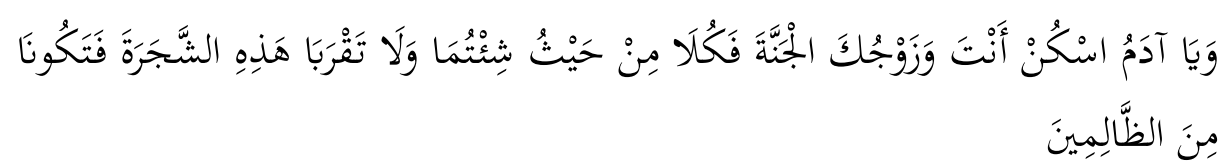

Dan Allah berfirman,'Wahai Adam! Tinggallah engkau bersama istrimu dalam surga dan makanlah apa saja yang kamu berdua sukai. Tetapi jangalah kamu berdua dekati pohon yang satu ini. (apabila didekati) kamu berdua termasuk orang-orang yang zalim."

Dalam menafsirkan dua ayat yang topiknya sama seperti di atas, Tafsir Ilmi Kementerian Agama memaparkan dua penafsiran. Penafsiran pertama yang secara umum dikenal yakni bahwa iblis menggoda Nabi Adam dan istrinya agar memakan buah "pohon terlarang" sebagaimana disebutkan dalam ayat, lalu setelah keduanya tergoda dan memakannya, keduanya menjadi telanjang dan menutupi aurat dengan dedaunan. Penafsiran yang tidak umum diambil dari pendapat Ali Raza Muhajir. Dalam 
penjelasannya sebagaimana dikutip oleh Tafsir Ilmi Kemenag, Muhajir berpendapat bahwa kata syajarah lebih tepat dimaknai dengan tindakan seksual. ${ }^{31}$

Contoh penafsiran lain adalah tentang Nabi Nuh dalam Q.S al-'Ankabūt [29]: 14 yang berbunyi:

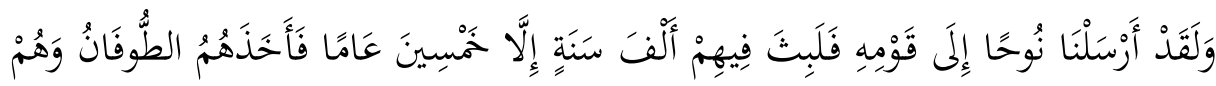

$$
\begin{aligned}
& \text { ظَاكِمُون }
\end{aligned}
$$

"Dan sungguh Kami telah mengutus Nuh kepada kaumnya, maka dia tinggal bersama mereka selama seribu tahun kurang lima puluh tahun. Kemudian mereka dilanda banjir besar, sedangkan mereka adalah orang-orang yang zalim.”

Penafsiran atas ayat di atas adalah bahwa Nabi Nuh berumur sekitar 950 tahun sesuai dengan keterangan dalam Perjanjian Lama yang juga menyebutkan angka yang sama. Angka ini mengindikasikan bahwa ajaran yang dibawa oleh Nabi Nuh berlaku selama itu hingga pada akhirnya datang Nabi Ibrahim dan hukum ajarannya diganti dengan ajaran Nabi Ibrahim.

Namun secara ilmiah, usia Nabi Nuh yang mencapai 950 tahun dapat dijelaskan karena sebelum banjir bandang, atmosfer bumi dilapisi oleh kanopi air yang lebih tebal dibandingkan yang sekarang. Lapisan kanopi air yang tebal ini berfungsi sebagai penangkal makhluk bumi dari paparan radiasi sinar ultraviolet (UV) yang pada gelombang tertentu dapat berpengaruh pada otak manusia yang mengakibatka lamanya waktu hidup manusia. Pada kenyataannya, setelah kanopi air dalam lapisan atmosfer itu pecah, dan atmosfer semakin menipis, rata-rata umur manusia semakin pendek dari sebelum-sebelumnya.

Dari dua contoh penafsiran di atas dapat ditarik benang merah bahwa dalam melakukan penafsiran, Tafsir Ilmi Kementerian Agama RI, tidak diawali dengan ayat terlebih dahulu, baru kemudian menentukan analisa dan tema, akan tetapi disusun tema dan topiknya terlebih dahulu, baru kemudian ayat-ayatnya disesuaikan dengan tema yang telah ditentukan. Pada akhirnya, analisa dan simpulan menyesuaiakan dengan tema dan topik pembahasan.

\footnotetext{
${ }^{31}$ LPMQ Kemenag RI, Kisah Para Nabi Pra-Ibrahim dalam Perspektif Alquran dan Sains, 37.
} 


\section{Signifikansi Tafsir Ilmi Kemenag dalam Khazanah Tafsir Ilmi}

Hal terpenting yang perlu digaris bawahi dari uraian panjang buku Tafsir Ilmi Kemenag Kisah Para Nabi Pra-Ibrahim adalah sikapnya terhadap teori evolusi Darwin. Tim mufassir tidak menolak sama sekali teori evolusi yang telah diterima secara luas dalam perkembangan ilmu saintifik. Salah satu ungkapan yang perlu dimunculkan dari pernyataan buku adalah sebagai berikut:

"Proses pentahapan ini (evolusi) tentu terjadi dalam skala waktu yang panjang, mencapai jutaan bahkan miliaran tahun. Namun dalam pandangan Sang Pencipta, Allah Ta'āla, kejadian ini tampak sekejap saja. Tafsir tentang penciptaan Adam dari tanah perlu didalami lagi sehingga penciptaan Adam dari tanah lebih bisa didekati secara lebih rasional., ${ }^{32}$

Pernyataan di atas jelas mengisyaratkan secara eksplisit bahwa evolusi manusia melalui tahapan yang sangat panjang selama berabad-abad hingga berjuta-juta tahun. Namun dalam proses yang sangat lama tersebut hingga memunculkan manusia modern seperti Nabi Adam dalam pandangan Allah swt tidaklah lama.

Berbeda dengan tafsir saintifik yang dibangun oleh Harun Yahya tentang teori Darwin. Yahya menolak teori evolusi dengan sangat keras dan membuat semacam teori kreasionisme yang berbasis pada Alquran. Teorinya ini kemudian diejawantahkan dengan bukunya yang berjudul Atlas of Creation. ${ }^{33}$

Perbedaan sikap ilmiah yang diambil Tafsir Ilmi Kementerian Agama menjadi hal baru dan pembeda dengan tafsir ilmiah semisal yang diutarakan oleh Harun Yahya. Secara garis besar, kesimpulan mengenai hubungan antara para Nabi dengan sejarah kebudayaan manusia dapat terlihat dari tabel di bawah ini:

\begin{tabular}{|c|c|c|c|c|c|}
\hline No & Nabi & $\begin{array}{c}\text { Dimensi Bentuk } \\
\text { Kebudayaan }\end{array}$ & $\begin{array}{l}\text { Dimensi } \\
\text { Ruang }\end{array}$ & $\begin{array}{l}\text { Dimensi } \\
\text { Waktu }\end{array}$ & $\begin{array}{l}\text { Kronologi } \\
\text { Relatif }\end{array}$ \\
\hline 1 & Adam & $\begin{array}{l}\text { Kemampuan } \\
\text { untuk belajar, } \\
\text { kemandirian } \\
\text { dalam bersikap, } \\
\text { mengenal } \\
\text { bercocok tanam } \\
\text { dan berternak } \\
\text { hewan peliharaan }\end{array}$ & $\begin{array}{l}\text { Kawasan } \\
\text { tropis dan } \\
\text { subtropis }\end{array}$ & $\begin{array}{l}\text { Awal } \\
\text { Revolusi } \\
\text { Pertanian } \\
\text { (Neolithic) }\end{array}$ & $\begin{array}{l}25.000-7.000 \\
\text { tahun yang } \\
\text { lalu }(7.000 \\
\text { tahun yang } \\
\text { lalu= 5000 } \\
\text { tahun } \\
\text { sebelum } \\
\text { masehi/SM) }\end{array}$ \\
\hline
\end{tabular}

${ }^{32}$ LPMQ Kemenag RI, Kisah Para Nabi Pra-Ibrahim dalam Perspektif Alquran dan Sains, 43.

${ }^{33}$ Haărun Yahyā, Atlas of Creation (Istanbul: Global Publisihing, 2006). 


\begin{tabular}{|c|c|l|l|l|c|}
\hline 2 & Idris & $\begin{array}{l}\text { Mampu } \\
\text { menguasai baca } \\
\text { dan tulis }\end{array}$ & - & $\begin{array}{l}\text { Pertengahan } \\
\text { Revolusi } \\
\text { Pertanian }\end{array}$ & - \\
\hline 3 & Nuh & $\begin{array}{l}\text { Papan, paku, } \\
\text { kapal besar, dan } \\
\text { kepemimpinan } \\
\text { masyarakat }\end{array}$ & Bukit Judi & $\begin{array}{l}\text { Akhir } \\
\text { Revolusi } \\
\text { Pertanian } \\
\text { sampai awal } \\
\text { Revolusi } \\
\text { Perkotaan }\end{array}$ & - \\
\hline 4 & Hud & $\begin{array}{l}\text { Bangunan, } \\
\text { Benteng, Negeri }\end{array}$ & $\begin{array}{l}\text { Iram, al- } \\
\text { Ahqaf }\end{array}$ & $\begin{array}{l}\text { Pertengahan } \\
\text { Revolusi } \\
\text { Perkotaan }\end{array}$ & - \\
\hline 5 & Salih & $\begin{array}{l}\text { Kemampuan } \\
\text { memahat gunung } \\
\text { dan membuat } \\
\text { istana }\end{array}$ & $\begin{array}{l}\text { Madain } \\
\text { Salih, al- } \\
\text { Hijr }\end{array}$ & $\begin{array}{l}\text { Pertengahan } \\
\text { Revolusi } \\
\text { Perkotaaan }\end{array}$ & - \\
\hline
\end{tabular}

Seperti terlihat dalam tabel, para nabi di atas mengisi bagian-bagian dari perkembangan sejarah manusia sejak beberapa abad sebelum tahun masehi. Nabi Adam as sendiri diperkirakan hadir ke muka bumi sejak 5000 tahun sebelum masehi. Hal ini menegaskan bahwa tafsir ilmi Kemenag tentang para Nabi pra-Ibrahim berposisi kontra dengan hipotesa yang dibangun oleh kalangan tafsir sastra yang berpendapat kisah para Nabi dalam Alquran tidak harus dipercayai sebagai kebenaran sejarah.

Lalu dimana posisi nabi Adam dalam kancah peradaban manusia masa lalu? Menurut tafsir ini, sebelum Allah swt menciptakan manusia modern, yang diawali oleh Nabi Adam as, telah ada makhluk yang menyerupai mansia disebut sebagai manusia purba. Manusia purba ini belum tergolong homo sapiens, yang besar otaknya belum sebesar manusia modern. Diterangkan bahwa makhluk ini sudah menghuni bumi sebelum datangnya nabi Adam. Hal ini diapat diketahui dengan pernyataan Malaikat yang mengetahi bahwa makhluk manusia purba ini sering berperang satu sama lain dan membuat kerusakan di muka bumi. ${ }^{34}$

Secara singkat, evolusi makhluk mirip manusia atau manusia purba dijelaskan dalam tafsir ini yaitu: ${ }^{35}$ (1) Jenis Sahelantropus (7 juta tahun yang lalu), antara lain: sahelanthropus tchadensis, (2) Jenis Orrorin (6 juta tahun yang lalu), antara lain: Orrorin tugenensis, (3) Jenis Ardiplthecus (5,5 juta-4,5 juta tahun yang lalu), antara lain:

\footnotetext{
${ }^{34}$ Q.S al-Bāqarah [2]: 30

${ }^{35}$ LPMQ Kemenag RI, Kisah Para Nabi Pra-Ibrahim dalam Perspektif Alquran dan Sains, 2930.
} 
Ardlpithecur kadabba, (4) Jenis Australophitecus (4-2 juta tahun yang lalu), antara lain: Australphitecus Anamensis dan Australophitecus africanus, (5) Jenis Parathropus (3-1,2 juta tahun yang lalu), antara lain: Parathropus Aethiopicus, (6) Jenis Homo (2 juta tahun yang lalu-sekarang), antara lain: Homo habilis (2,4-1,4 juta tahun yang lalu), Homo erectus (1,8-70.000 tahun yang lalu), Homo neanderthalensis (250.000- 30.000 tahun yang lalu), Homo sapiens (250.000- sekarang).

Diyakini bahwa homo sapiens adalah satu-satunya jenis dari marga hom oyang tidak punah. Banyak jenis hom lainnya yang hidup di masa lalu sudah punah dari muka bumi. Berikut ilustrasi gambar yang ditampilkan terkait dengan perkembangan tengkorak makhluk seperti manusia.

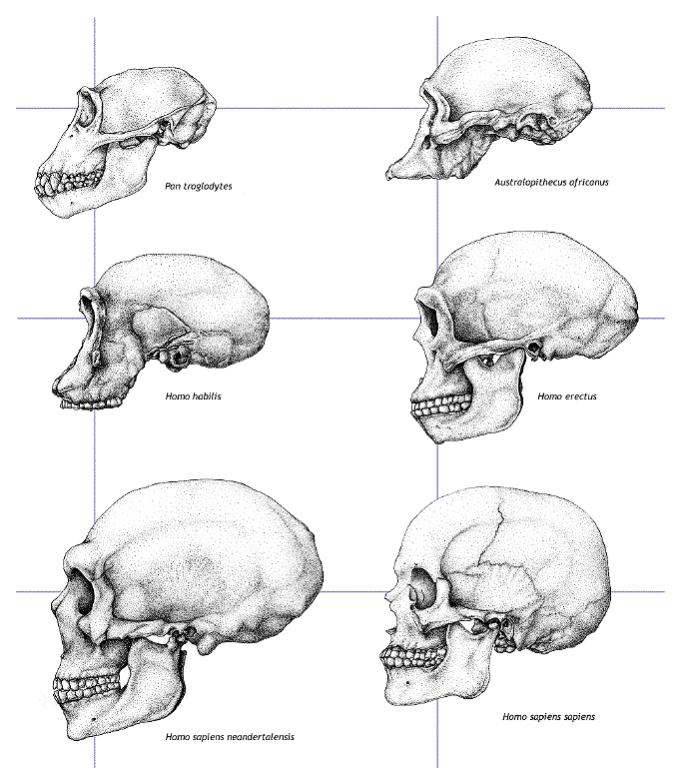

Jika kembali melihat tabel keberadaan Nabi Adam di muka bumi yang dituliskan ada sejak 5000 tahun SM, maka eksistensi homo sapiens sendiri diperkirakan sudah ada sejak 20.000 tahun sebelum Nabi Adam hadir. Terlepas dari perdebatan benar atau tidaknya teori evolusi Darwin, penting disimak argumentasi yang disuguhkan para mufassir yang menolak mentah-mentah eksistensi tafsir ilmi, khususnya datang dari kalangan mufasir sastra.

Salah satu tokoh yang mengungkapkan hal ini adalah Aḥmād Khalafullāh dengan karyanya al-Fānn al-Qașāṣ̄ fĭ al-Qur'ān. Tesis yang dibangun Khalafullāh adalah bahwa Alquran bukanlah kitab sejarah. Sama seperti gurunya, Amīn al-Khulī, Khalafullah beranggapan bahwa kisah-kisah dalam Alquran perlu disikapi sebagai bagian dari sastra alegoris. Hal ini dibuktikan dengan tidak ada detail data sejarah yang 
ditampilkan Alquran. Oleh karenanya, yang terpenting dari kisah-kisah tersebut adalah nilai moral dan pelajaran yang terkandung didalamnya. ${ }^{36}$

Akan tetapi, ketika membaca kisah para Nabi dalam Alquran melalui perspektif saintifik-arkeologis, tim Tafsi Ilmi Kementerian Agama sepenuhnya sadar dengan kontroversi yang muncul di kalangan para mufassir tentang kredibilitas tafsir ilmiah ini. Bahkan dalam pengantarnya, Muchlis M. Hanafi sebagai bagian dari tim membeberkan tiga faktor kelemahan yang ada dalam tafsir ilmi secara keseluruhan. Pertama, kerapuhan tafsir ilmi secara filologis, kedua kerapuhan tafsir ilmi secara teologis, dan ketiga kerapuhan tafsir ilmi dari sudut pandang logika. ${ }^{37}$

Dari sisi filologis/kebahasaaan, Alquran diturunkan kepada bangsa Arab sesuai dengan kadar kemampuan bahasa mereka. Artinya, Alquran tidak memuat sesuatu yang tidak dipahami oleh masyarakat Arab pada masa itu. Rasūlullāh tidak pernah mensabdakan bahwa Alquran adalah sumber ilmu pengetahuan saintifik dan sebagainya. Begitu pun dilihat dari sudut pandang teologi, Alquran adalah kitab petunjuk yang membawa pesan etis, syariah, dan akidah, bukan merupakan buku ilmu pengetahuan untuk menemukan teori-teori ilmiah baru. Sama halnya dari sudut pandang logika, ilmu pengetahuan bersifat relatif dan subjektif, maka tidak dibenarkan apabila Alquran dianggap sebagai kitab yang relatif juga subjektif yang bisa berubah sesuai dengan perubahan teori ilmu pengetahuan manusia.

Namun demikian, Kementerian Agama tidak menjadikan tiga faktor di atas sebagai penghalang dilakukannya penafsiran saintifik atas Alquran. Menurut Muchlis M. Hanafi, baik tafsir yang bercorak hukum (fikih), teologi, dan etika di masa lalu adalah bagian dari produk ijtihab para ulama yang diupayakan demi kemaslahatan umat. Sama halnya dengan tafsir saintifik ini yang juga produk ijtihad. Yang penting dikedepankan adalah kehati-hatian dan kerendah hatian para mufassir pada saat menafsirkan Alquran. Tafsir dengan berbagai bentuk dan variannya, hanyalah upaya manusia yang terbatas untuk memahami maksud kalam Tuhan yang tidak terbatas.

\footnotetext{
${ }^{36}$ Muhammad Aḥmād Khalafullāh, al-Fānn al-Qașași fi al-Qur'ā' (Bairūt: al-Ansyār al-'Arabī, 1999), 225.

${ }^{37}$ Muchlis M. Hanafi, "Memahami Isyarat-Isyarat Ilmiah Alquran: Sebuah Pengantar" dalam Kisah Para Nabi Pra-Ibrahim dalam Perspektif Alquran dan Sains, xxiv-xxv.
} 


\section{Kesimpulan}

Dari pemaparan dan uraian di atas, dapat disimpulkan bahwa komitmen awal yang diperlihatkan oleh tim Tafsir Ilmi Kementerian Agama adalah membentuk sintesa antara Alquran dan teori saintifik yang sedang berkembang. Bukan berada para ranah mempertentangkan dan menonjolkan argumentasi-argumentasi teologis guna menolak teori sains yang sedang berkembang.

Hal ini terlihat dari sikapnya terhadap teori evolusi Darwin yang diterima secara luas oleh para saintis, Tafsir Ilmi khususnya dalam buku Sejarah Para Nabi Pra-Ibrahim ini tidak menolak sama sekali teori tersebut. Akan tetapi mencoba mencari titik temu dan sisi rasionalitas yang didukung dengan ayat-ayat Alquran guna memahami teori evolusi tersebut.

\section{Daftar Pustaka}

Abū Khalīl, Syauqī. Ațlāṣ al-Qur'à': Amākin, Aqwān, A'lām. Bairūt: Dār al-Fikr alMu'āṣir, 2003.

Davidson, Herbert A. Alfarabi, Avicenna, and Averroes on Intellect: Their Cosmologies, Theories of the Active Intellect, and Theories of Human Intellect. Oxford: Oxford University Press, 1992.

Faizin. “Integrasi Agama Dan Sains Dalam Tafsir Ilmi kementrian Agama RI” Jurnal ushuluddin 25, 1 (2017).

Fikriyati, Ulya. "Tafsir Ilmi Nusantara: Antara Kepentingan Ideologis dan kebutuhan Pragmatis: Menimbang Tafsir Karya Ahmad Baiquni.” Jurnal Al-Burhan XIII, 2 (2013).

Ghazālī, Abū Ḥamīd. al-Ihyyā' Ulūm al-Dīn. Bairūt: Dār al-Ma'rifah, T.t.

Jauhārī, Tanțāwī. Al-Jawāhir fì al-Tafsīr al-Qur'ān al-Karīm: al-Musytamil 'Alā 'Ajā'ibi Badā'i al-Mukawwanāt wa Gharā'ib al-Āyatt. Qāhirah: Musțafa alBābī, 1351.

Khalāfullāh, Muḥammad Aḥmād. al-Fānn al-Qaṣāṣ̄i fĭ al-Qur'ān. Bairūt: al-Ansyar al‘Arābī, 1999.

Shohib, Muhammad. Kisah Para Nabi Pra-Ibrahim Dalam Perspektif Alquran dan Sains. Jakarta: Kemenag, 2012. 
Julkarnain, Muhammad. "Epistemologi Tafsir Ilmi Kemenag: Tumbuhan dalam Perspektif Alquran dan Sains”. Jurnal Penelitian Keislaman 10, 1 (2014).

LPMQ Kemenag RI. Kisah Para Nabi Pra-Ibrahim dalam Perspektif Alquran dan Sains. Jakarta: Kemenag RI, 2012.

Al-Maghlūs̀, Samī’ ibn 'Abdullāh. Ațlāṣ al-Anbiyā' wa al-Rusūl. Riyāḍ: Maktabat al'Abīkan, 2005.

Mustaqim, Abdul. Dinamika Sejarah Tafsir Alquran: Studi Aliran Aliran Tafsir dari Periode Klasik, Pertengahan, Hingga Modern-Kontemporer. Yogyakarta: Adab Press, 2012.

Rohimin. “jejak Dan Otoritas Pencetakan Mushaf Alquran di Indonesia”. Nuansa IX, 2 (2016).

Rohmansyah. “Corak Tafsir Muhammadiyah” Jurnal Ushuluddin 26, 1 (2018).

Yahyā, Ḥarūn. Atlas of Creation. Istanbul: Global Publishing, 2006.

Żahabi, Muhamammad Ḥusain al-Tafsīr wa al-Mufassirūn. Qāhirah: Maktabah Wahbah, T.t.

Zarqani, Muhammad Abd al-Azim al-. Manahil al-'Irfan fi 'Ulum Alquran. Beirut : 'Isa al- Bab, juz 2. tth.

Zarkasyi, Badruddin al-. al-Burhan fi Ulum Alquran. Kairo: Dar Ihya al-Kutub al'Arabiya, 1954. 